\title{
Anatomical Study of the Digits of Fore limbs in goat
}

\author{
H. A. Al- Sharoot Th. A. Abid E. F. AL-Baghdady
}

Coll. of Vet. Med./.Univ. of Al-Qadisiya.

\begin{abstract}
The study aim to explain the anatomical description of the digit of fore limb in goat (Capra hircus). Left and right fore limbs of 10 Iraqi healthy male goats aging (6) months, with no history of lameness and without local swelling or joint distension were utilized in this study. The study reveals that the goats have two digits; each digit has three phalanges (pI, p II, p III) and sesamoid bones. The PI longer than the other phalanx while the pII was much shorter than the pI. PIII was uniquely triangular in shape with numerous vascular channels. The proximal sesamoid bones were elongated and each bone have three surfaces while distal sesamoid bones were shuttle in shape and situated palmer to the second interphalangeal joints.

Key word: Anatomical, Digits, Goat (Capra hircus)

Introduction

Goats (Capra hircus) are small important domesticated ruminants which has served humans earlier and longer than cattle and sheep $(1,2)$. Goats are wide spread across the world, having adapted to many different climatic conditions and econiches (3) .It can be found in all over the world particularly in arid semitropical or mountainous countries (4) .More differenced between types of animals in the limb. Some types characteristic by contain fate fibrous layer cover distal phalanx and distal part of phalanx called nail or hoof

(Digitigrades) for example dog (5).While anther type of animals limb characteristic by the stronger feet for the tension and pressure, this type of animals located under (Unguligrade) for example ruminant (6) .The importance of the foot resides from the complex anatomical peculiarities, the biomechanical stress and the multitude of clinical conditions that are related to this region. Due to the complexity of anatomical structures located on the palmer aspect of the foot, this region is much more predisposed to injuries $(7,8)$
\end{abstract} ,this type of animals located under

\section{Materials and Methods}

Ten fore limbs of ten Iraqi healthy male goats aging (6) months, with no history of lameness and without local swelling or joint distension for the anatomical study were collected immediately after slaughter and kept in clean plastic container until transported to the laboratory in ice cold water bags to

\section{Skeleton of Digit under Carpal Joint 1- Digits of Goat}

The goat has two digits the (III) and (IV). The first digit was absent, the 2nd, and 3rd were remaining as dewclaw. Each digit consists of three phalanxes (the proximal, middle and distal phalanx). The proximal phalanx of each digit (III, IV) appears foursided and, longer than the other phalanxes.

\section{Result}

perform the required examinations. The limbs were prepared by carefully dissecting the skin using surgical scalpel and surgical scissors. After dissection the following measurements were taken, the length, the width, and the thickness (proximal, middle and distal) phalanxes of the third and fourth digit in right and left fore limb.

The shaft or body was thick proximally and have four surfaces. The dorsal surface was smooth, and convex from side to side (Fig.1A), the palmer surface was flat and have rough area for attachment of the distal sesamoid ligament (Fig.1B). The axial and abxial surface were rounded. The mean length of the (III) and (IV) proximal 
phalanxes in both the left and right fore limbs was equal (Table.1).

The proximal articular extremity was large and consisted of two parts (cavities) separated by sagittal groove. The lateral part was wider and lower than the medial one (Fig.1C). Palmarly there were two facets articulated with the proximal sesamoid bones. The mean width and thickness of the proximal extremity of the third digit was differ than of that of both the fourth digit in the right and left fore limb fore limb (Table.1).The distal articular extremity consisted of two symmetrical condoyles (lateral and medial). The lateral condoyle was larger than the medial. These condoyles articular with the proximal extremity of the middle phalanx (Fig. 1D) .The mean width and thickness of the distal extremity in the third digit was slightly differ than that of the fourth digit in both the right and left fore limb (Table. 1).

(Table. 1) The morphmetric measurements of the proximal phalanx of third and fourth digit in the right and left fore limb in goat. $n=10, M \pm S E(\mathrm{~cm})$

\begin{tabular}{|l|ccc|c|}
\cline { 2 - 6 } \multicolumn{1}{c|}{} & \multicolumn{2}{c}{$\begin{array}{c}\text { Right limb } \\
(\mathbf{c m})\end{array}$} & \multicolumn{2}{c|}{$\begin{array}{c}\text { Left limb } \\
(\mathbf{c m})\end{array}$} \\
\cline { 2 - 6 } & Third digit & Fourth digit & Third digit & Fourth digit \\
\hline phalanx Length & $2.3 \pm 0.08$ & $2.3 \pm 0.08$ & $2.3 \pm 0.08$ & $2.3 \pm 0.08$ \\
\hline Width of proximal extremity & $1.38 \pm 0.04$ & $1.19 \pm 0.04$ & $1.37 \pm 0.05$ & $1.18 \pm 0.05$ \\
Width of distal extremity & $1.47 \pm 0,19$ & $1.3 \pm 0.18$ & $1.45 \pm 0.2$ & $1.27 \pm 0.18$ \\
Thickness of proximal & $1.36 \pm 0.04$ & $1.18 \pm 0.03$ & $1.37 \pm$ & $1.19 \pm 0.03$ \\
\hline Thickness of distal extremity & $1,27 \pm 0.08$ & $1,18 \pm 0.08$ & $1,3 \pm 0$. & $1,16 \pm 0.08$ \\
\hline
\end{tabular}

The middle phalanx (PII) was shorter in length than $\mathrm{pI}$.Its mean length was equal in both the right and left fore limbs (Table.2). It has two extremities (Fig .2A). The proximal articular extremity consisted of two cavities (Lateral and medial cavity) separated by prominent sagittal ridge, articulated with the distal extremity of the proximal phalanx . The Lateral cavity was larger than the medial cavity (Fig .2B).The mean width and thickness of the proximal extremity in the third digit slightly different than that of the fourth digit in both the right and left fore limb (Table.2). The distal articular extremity was similar in structure of that in pI, while its mean width and thickness of distal extremity of the third digit was slightly different than that of the fourth digit in both the right and left fore limbs (Table. 2). 
(Table 2) The morphmetric measurements of the middle phalanx of third and fourth digit in the right and left fore limb in goat. $\mathrm{n}=10, \mathrm{M} \pm \mathrm{SE}(\mathrm{cm})$

\begin{tabular}{|c|c|c|c|c|}
\hline \multirow[b]{2}{*}{ Middle phalanx } & \multicolumn{2}{|c|}{$\begin{array}{l}\text { Right limb } \\
\text { (cm) }\end{array}$} & \multicolumn{2}{|l|}{$\begin{array}{c}\text { Left limb } \\
\text { ( cm) }\end{array}$} \\
\hline & Third digit & Fourth digit & Third digit & Fourth digit \\
\hline phalanx Length & $1.25 \pm 0.08$ & $1.25 \pm 0.08$ & $1.25 \pm 0.08$ & $1.25 \pm 0.08$ \\
\hline Width of proximal extremity & $1.24 \pm 0.05$ & $1.04 \pm 0.05$ & $1.25 \pm 0.04$ & $1.06 \pm 0.05$ \\
\hline Width of distal extremity & $0.88 \pm 0$ & $0.72 \pm 0.06$ & $0.96 \pm 0.06$ & $0.77 \pm 0.05$ \\
\hline Thickness of proximal extremity & $1.15 \pm 0.04$ & $1.05 \pm 0.02$ & $1.17 \pm 0.03$ & $1.07 \pm 0.02$ \\
\hline Thickness of distal extremity & $0.95 \pm 0$ & $0.83 \pm 0.07$ & $0.97 \pm 0.06$ & $0.85 \pm 0.07$ \\
\hline
\end{tabular}

The distal phalanx was entirely enclosed by the claw. It was triangular in shape and has four surfaces. The axial surface was smooth proximally and has numerous vascular foramina distally. The proximal articular surface appears confined from side to side, oblique palmarly, comprised from two sided and consist of two cavities separated by prominent ridge Articulated with the middle phalanx and articulated with the distal sesamoid bone by the flat surface located along the palmer border of the proximal articular surface called the articular sesamoid surface (Fig.3A). The mean width and thickness of the articular surface in the third digit slightly different from that of the fourth digit in both the right and left fore limb (Table. 3). The parietal surface have more vascular foramina (Fig. 3B).The solar surface concave, irregular and, divided by the semiluner line in to two parts, the dorsal part was the largest than the palmer part, also called the flexor surface. The coronary or the dorsal border had a rough, pointed eminence for the insertion of the common digital extensor tendon.

(Table 3) The morphmetric measurements of the distal phalanx of third and fourth digit in the right and left fore limb in goat. $\mathrm{n}=10, \mathrm{M} \pm \mathrm{SE}(\mathrm{cm})$

\begin{tabular}{|l|cccc|}
\cline { 2 - 5 } & \multicolumn{2}{c|}{$\begin{array}{c}\text { Right limb } \\
(\mathbf{c m})\end{array}$} & \multicolumn{2}{c|}{$\begin{array}{c}\text { Left limb } \\
\text { ( cm) }\end{array}$} \\
\cline { 2 - 6 } & Third digit & Fourth digit & Third & Fourth digit \\
\hline Width of articular surface & $0.97 \pm 0.04$ & $0.8 \pm 0.05$ & $1.04 \pm 0.04$ & $0.81 \pm 0.05$ \\
Thickness of phalanx & $1.07 \pm 0.03$ & $1 \pm 0.01$ & $1.04 \pm 0.04$ & $1 \pm 0.01$ \\
\hline
\end{tabular}

The studies demonstrate that the fetlock joint was completely spherical or rounded in shape while the first interphalangeal joint was crescent-shaped. The fetlock joints surrounded by hard and soft tissue structures and composed of multiple hard and soft tissues. The dorsal surface of the joints capsule of the fetlock, first interphalangeal and the second interphalangeal joint cover by the extensor digital tendons, while the palmer surface was covered by flexor digital tendons, where the medial and the lateral sides of the joints were supported by the collateral 
ligaments. The capsule of fetlock joints was wider than the capsule of the pastern joint. The second interphalangeal joint was resemble the first interphalangeal joints. Four proximal sesamoid bones were present for each fore limb of goat, two for each digit located palmarly to the fetlock joints. Each sesamoid bone has three surfaces, apex and base. The articular surface palmarly articulated with the distal part of the large metacarpal bone and the proximal phalanx. The flexor surface was flat and oblique, while the lateral surface was convex. The base was located distally and attached with the distal sesamoid ligament. The apex was rounded and located proximally.
Two distal sesamoid bones in number were found for each fore limb of goat, one sesamoid bone for each digit. It was shuttle in shape and situated palmer to the second interphalangeal joints. It had one articular surface, two borders and two extremities. The articular surface consisted of two parts separated by a central elevated eminence and articulated with the distal end of pII. The flexor surface was same as the articular surface but rougher. The proximal border was rough for ligaments attachment and the distal border had facet for articulation with the palmer surface of pIII. The two extremities of the bone were irregular in shape.
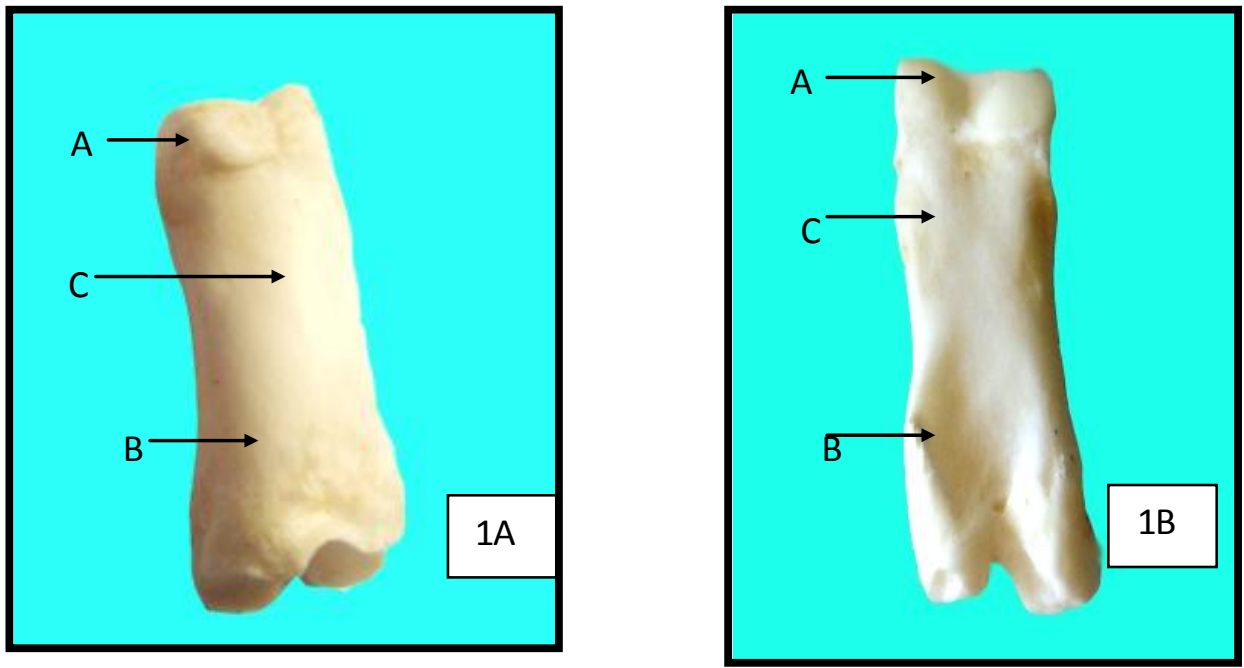

Fig (1A) dorsal surface; Fig (1B) Palmer surface of proximal phalanx

A. proximal extremity of proximal phalanx of proximal phalanx;B. Distal extremity of proximal phalanx; C. Body 

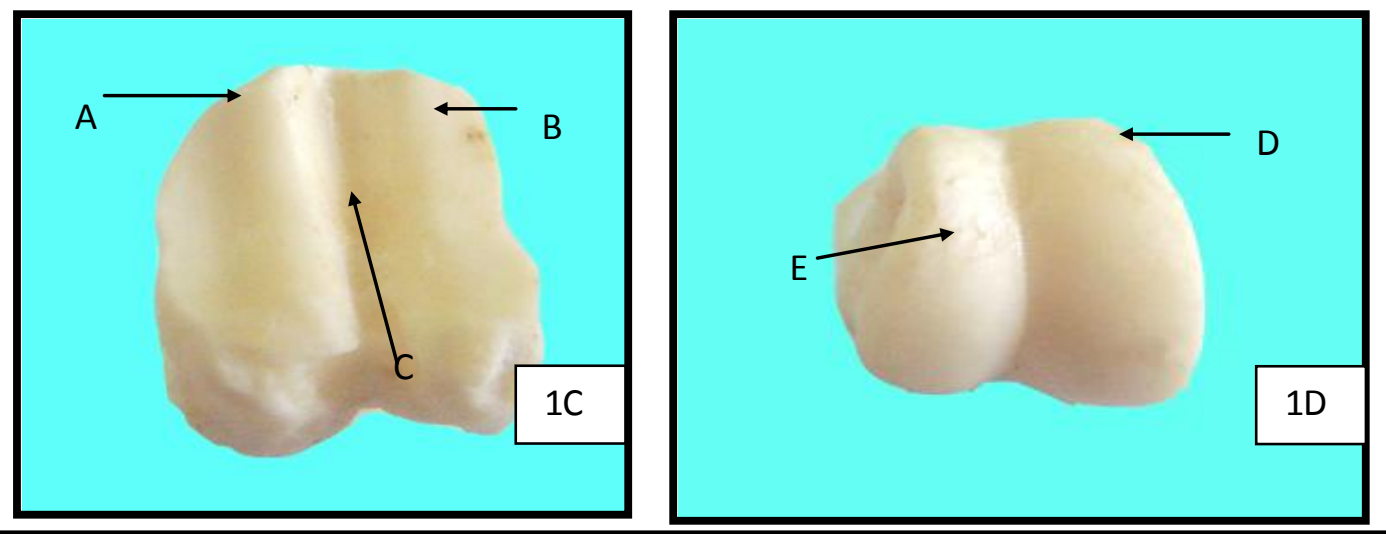

Fig (1C) proximal extremity of proximal phalanx; Fig (1D) Distal extremity of proximal phalanx

A. Iateral cavities; B. medial cavities; C. sagittal groove; D. Iateral condoyle; E. medial condoyle
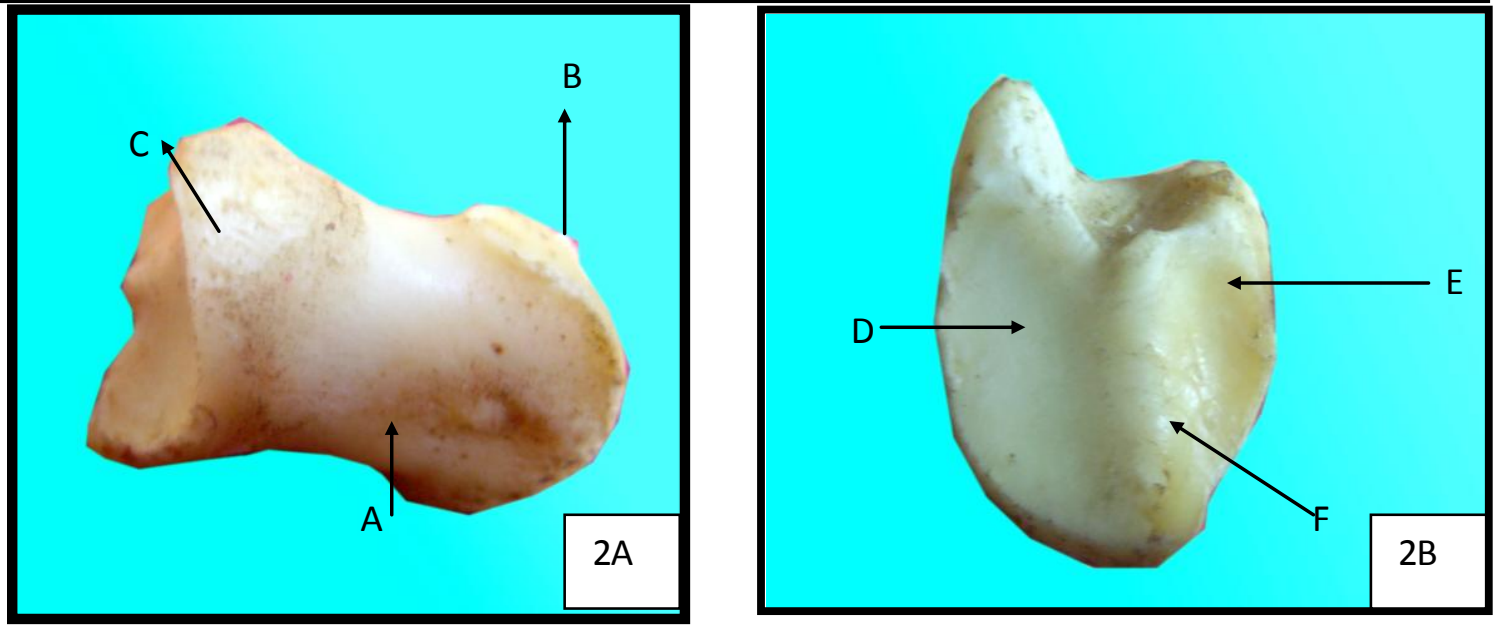

Fig (2A) Middle phalanx; Fig (2B) proximal extremity of middle phalanx

A. Body of middle phalanx; B. proximal extremity of middle phalanx;C. Distal extremity of middlephalanx;D. .lateral cavities; E. medial cavities; F. sagittal groove

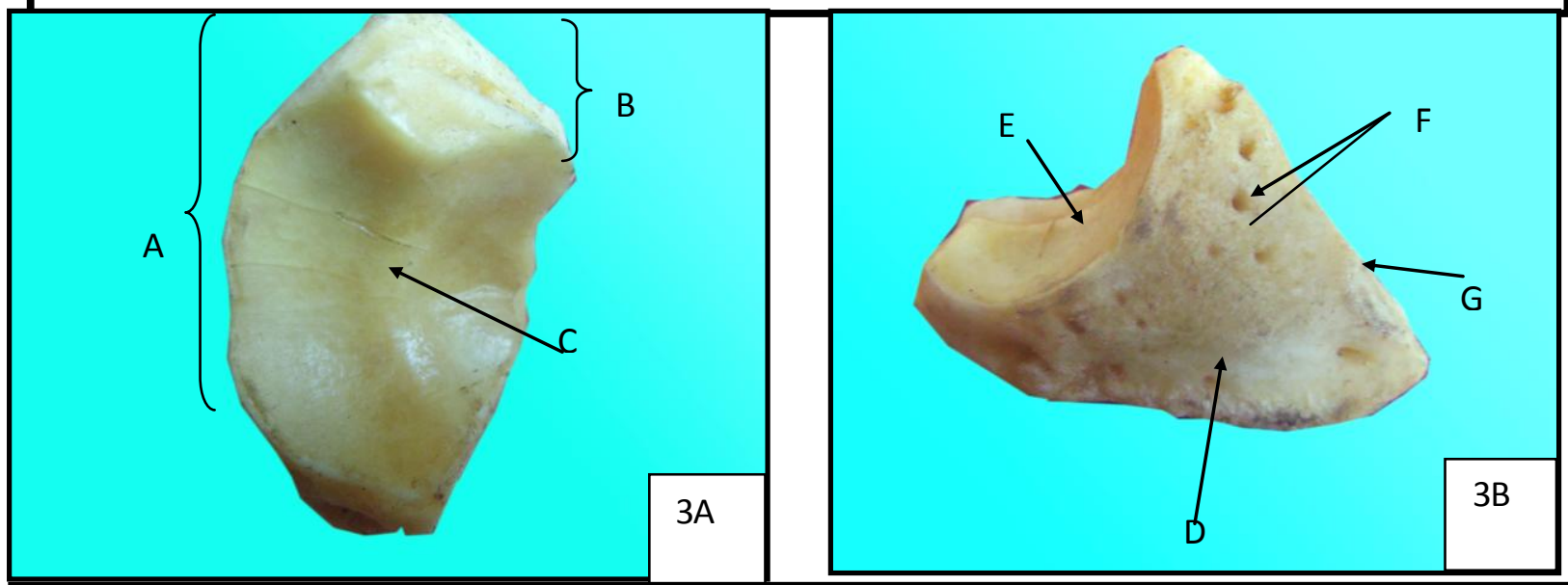

Fig (3A) Proximal articular surface of distal Phalanx; Fig (3B) lateral side distal Phalanx

A.articular surface with the middle phalanx; B. articular surface with the distal sesamoid bone, C. prominent ridge; D. Parietal surface of distal Phalanx, E. articular surface with the middle phalanx, F. vascular foramina, G. dorsal border 


\section{Discussion}

Study confirmed, two fully developed digits (III) and (IV) in goats. The first digit is absent, the second and fifth was remaining as dewclaw. Each digit in goats consist of the (proximal, middle and distal phalanx) .The present observations are consistence with those observations of (11) and (15) in cattle, sheep and goats. Each phalanx (proximal and middle) consists of body and two extremities. The body has dorsal and palmer surfaces, the dorsal surfaces smooth, convex from side to side, while the palmer surface flat and have rough area for attachment with the ligament, that is disagreed with (9) who presented in camels the body of the (proximal and middle) were large, long and the two extremities of the proximal and the middle phalanxes were pointed. The distal phalanx was uniquely triangular in shape, its much smaller than the other phalanxes, further more, the parietal surface of PIII has more nutrient foamen for the pass of artires that is in agreement with (10) in impala, and (11) in goat .The proximal articular surface appears confined from side to side, oblique palmary, comprised from two sided for the articulation with the middle phalanx and with the distal sesamoid bone. This result confirmed the studies of (6) in cattle and sheep. The study declares that goats have spherical fetlock joint was surrounded by hard and soft tissue structures. Capsule of fetlock joints is wider than the capsule of the pastern joint due to the presence of proximal sesamoid bones which help to increase extension of the capsule. This is in accordance with (12), and (6) in ox. The study observed four proximal sesamoid bones were present in goat, two for each digit. The proximal sesamoid bones are encased within the elastic suspensory ligament proximally and the nonelastic distal sesamoidean ligaments distally on the palmer surface of the fetlock joint because that proximal sesamoid bones provide stability to the suspensory apparatus as, by acting as lever arm for the suspensory apparatus. This result confirmed the studies of (13), and (14) in horses, (11) in goats, and (6) in cattle and sheep.Distal sesamoid bones in goats are two in number, one for each digit shuttlelike in shape, situated palmer to the second interphalangeal joints because that it increased the surface area of the coffin joint and reduced the impact loading of the deep digital flexor tendon away from the centre of the coffin joint. This finding seems consistent with (15), (16), and (6) in horse and cattle, while disagreed with the (17) who presented that the distal sesamoid bone in camels disappear.

\section{Reference:}

1-Yalcin, B. C. (1986). Sheep and goats in Turkey. Anim. Prod. Health. FAO. 60

2- Haenlein, G. F. (1992). Digestion extension goat handbook. ttp $/ / \mathrm{www}$. inform.umd.edu/EdRes TTopic

/AgrEnv/ndd/goat.digestion.htm

3- Al-Baggal, H. A.R., Al-Dahash, S.Y. A. and Alwan, A.F. (1993). Macroscopic study of the female genital system in Iraqi goats. Small. Rum. Res. 9: 341-346.

4-Noseir,M.B.,Kassem,M. Mand ELAmrawy (1987). Ovariohysterectomy in different stages qf gestation,Assiut. Vet.Med.J.18(36) :172-175.

5- Donald, E.T., and LAN, D.R., (2011). Atlas of normal radiographic anatomy and anatomic variants in the dog and cat $6^{\text {th }}$ Ed.,pp. 95-97. 
6- Dyce, K.M., Sack, W.O and Wensing, C.J. (2010). Textbook of Veterinary anatomy, W.B. Saunders Company, Harcaurt Barcjovanvich, Inc.Phildadelphia, .pp.727-739.

7- Praks A. (2006). Structure and function of the equine digit in relation to the palmer foot pain In: 52 Annual Convention of the American Association of Equine Practitioners, San Antonio, TX, USA. (Ed.).

8-Theoret ,C. (2006). Anatomy of the Distal Limb and How It Relates to Wounds in this Area, NAVC Proceedings. Internet Publisher: nternational Veterinary Information Service, Ithaca NY (www.ivis.org), last updated: 11Jan-2006.

9- Marcos, B.M. (1955). The anatomical study of the joints of the camel, Msc.Thesis, Cairo. University, Egypt 18-76.

10-Mostafa, M., Koma, L. M., and Ssengoba, O. (2006). Radiographic visualization of the metacarpus and phalanges in the impala (Aepyceros melampus) . Vet. Archive 76: 75-83.

11- Siddiqui, M. S. I., Khan, M. Z. I., Moon, S., Islam, M. N., and Jahan, M. R. (2008): Macro- anatomy of the bones of the fore limb of black bengal goat (CAPRA HIRCUS) . Bangl. J. Vet. Med. 6(1): 59-66.

12- Budras, K.D., and Röck, S. (2004). Atlas der Anatomie des Pferdes, 5th edn.,Schültersche $\mathrm{GmbH} \&$ Co., Hannover, Germany. pp 1011.

13-Bukowieki, CF., Bramlage, LR. and Gabel, AA. (1985) Proximal sesamoid bone fractures in horses: Current treatments and prognoses.Compend Contain Educe Pract Vet 7: S684 - S698.

14- Hubert, J.D., Latimer, F.G.,and Moree, R.M. (2001): Proximal sesamoid bone fractures in horses. J. Anat . 23(7):678-685.

15- Getty, R. (1975).The Sisson and Grossman's Anatomy of the Domestic Animal 5th Ed.,Philadelphia, USA. pp. 748762.

16- Loving, N., and Johnston, A. M. (1995): Veterinary Manual for Performance Horse Blackwell Ltd. pp. $66-68$.

17-Ral, V.P., Tich, F., and Fabi, M. (2004). Functional structure of metapodial bones of cattle .J. Acta. Vet. Slovac University of Agriculture in Nitra, Slovakia .73:413-420. 


\section{دراسة تثريحية للأصبع في ألماعز

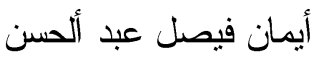 \\ ثاير علوان عبد \\ حسنين علي ألثاروط \\ كلية الطب البيطري/جامعة القاسية \\ ألخلاصة}

تناول البحث دراسة تشريحية للأصبع للقائمة الأمامية في الماعز . استخدم في هذه الدراسة عشرة أطراف أمامية من عشرة حيوانات ذكور عراقية, أعمارها (6) أثنهر , أطر افها سليمة ليس تاريخ بالعرج, أورام موضعية و إصابات مفصلية

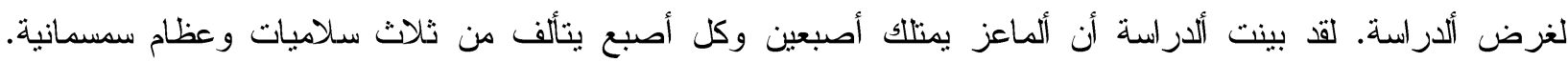
السلامية الأولى هي أطول ألسلاميات بينما السلامية الثانية فهي أقصر من ألسلامية ألأولى.السلامية ألثالثة مثلثة ألثنكل وتمنلك ألعديد من القنوات الوعائية .ألعظام السمسمانية ألدانية تكون منطاولة في ألثنكل وكل عظم يتألف من ثلاثثة سطوح أما العظام السمسمانية القاصية تكون مكوكية الثكل يقع راحيا للمفصل المتكون بين السلاميتين الوسطى و القاصية.

| (بحث مستل من رسالة ألماجستير للباحث ألأول 